\title{
TERRITORIAL POLITICS IN NATIVE-BRAZILIAN BACKWOODS, XIX CENTURY
}

\author{
Política territorial nos sertões dos índios, século XIX \\ Maria Isabel de Jesus Chrysostomo* \\ Higor Mozart Geraldo Santos **
}

\begin{abstract}
Resumo
Discutimos, neste trabalho, a política de expansão e controle territorial proposta para a região fronteiriça entre os sertões do Rio de Janeiro e Minas Gerais no século XIX. Nossa intenção é apresentar como as autoridades dessas províncias pensaram a política de colonizacão das terras indígenas e identificar algumas de suas estratégias territoriais. Centraremos nossa análise na área entre Campos (RJ) e Muriaé (MG) com vistas a compreender como o projeto para civilização dos índios contribuiu para transformar política e economicamente esta ampla região, o que redundou em conflitos territoriais que expressaram diferentes projetos e usos do território.
\end{abstract}

Palavras-chave: Índios; Política territorial; Sertões de Muriaé e Campos; Civilização.

\begin{abstract}
In this work we discuss the expansion politics and proposals of territorial control for the borderland zone between the backwoods of Rio de Janeiro and Minas Gerais in the 19th century. We aim at presenting the ways in which the local authorities of these provinces planned the colonization of indigenous lands, as well as identifying some of their territorial strategies. We focus our analysis in the area between Campos (RJ) and Muriae (MG), with the intention of comprehending how the project of civilizing the Natives contributed for the political and economic transformation of this wide region, which resulted in territorial conflicts that expressed different uses and projects for that territory.
\end{abstract}

Key words: Native-Brazilian; Territorial Politics; Backwoods of Muriaé and Campos; Civilization.

\section{Résumé}

Nous discutons, dans ce travail, la politique d'expansion et de contrôle territorial proposée pour la région frontalière des sertões de Rio de Janeiro et de Minas Gerais à la fin du XIXe siècle. Notre but est de montrer comment les autorités de ces provinces ont pensé la politique de colonisation des terres indiennes et d'identifier quelques-unes de leurs stratégies territoriales. Nous centrons notre analyse sur la région comprise entre les villes de Campos (RJ) et Muriaé (MG) de façon à illustrer la façon dont le projet de civilisation des indiens a contribué à transformer politiquement et économiquement cette région. Ainsi, les conflits territoriaux sont-ils l'expression de différents projets et usages du territoire.

Mots clés: Indiens; Politique territoriale; Sertões de Muriaé et Campos; Civilisation.

(*) Lecturer, Doctor of the Federal University of Viçosa (Universidade Federal de Viçosa) - Avenida P.H. Rolfs, s/nº, Campus Universitário, CEP: 36.570-000. Viçosa (MG), Brasil. Tel: (+55 31) 38994053 - isachrysostomo@ufv.b

(**) Msc. Universidade Federal de Juiz de Fora - Rua José Lourenço Kelmer, s/n, Campus Universitário, CEP: 36036-900, Juiz de Fora (MG), Brasil . Tel: (+55 31) 38994053 - hmozart@gmail.com 


\section{INTRODUCTION}

The backwoods' occupation proposals were tied to a policy marked by two main goals: the land regulation and the installation of a new model of land occupation within indigenous patrimony. Inherited from the Marquis of Pombal's modernizing project, in the mid XIX century, this policy featured the creation of bureaus intended to manage the indigenous homeland. The idea was to expand the "arms" of the State to the different areas occupied by the natives, trying to integrate those areas into the more economically developed regions. From such perspective, for bringing up an association between West Indians and borders, the "indigenous land civilizatory and administrative policy" redefined the geopolitical strategy of turning the territory laic, first initiated by Pombal .

The first moment of the indigenous land appropriation is related to the colonization process and has, as its precursor elements, the ideological discourses on the backwoods, deserts, and confines. Such areas, occupied by several indigenous nations, were usually associated with disorder, savagery, emptiness and backwardness. After the Independence, such discourses were aligned to the idea of a "scientific" management of the indigenous land and to the inhabitation policy. In this context, the arguments applied for the occupation of these territories constituted one of the main resources mobilized by the State in order to legitimize the transformation of these vast regions.

However, besides that, this process was also encouraged by the interests of the local elites to expand their political and economic power in the areas considered potentially useful. Thus, if the natives and their villages acted as "barriers of the backwoods" (ALMEIDA, 2008) during the XVIII century, in the following century there were other roles for these spaces, amongst which there was the need to give support to civilizing processes required to strengthen the newly created nation. These projects, therefore, define a new territorial order in the indigenous backwoods.

As pointed out by Moraes $(1988 ; 2000 ; 2002)$, the clues left in the discourses and diagnostics on the backwoods-generally situated in the borders-reinforce the need to analyze the geographical ideologies that sponsored the territorial policies. Following his advice, in this article we aim at understanding how the propositions and representations of the backwoods located between Muriaé and Campos were elaborated to justify the installation of new infrastructure, villages and towns from the XVIII century on. We comprehend that the set of civil, military, and religious interventions became one of the main resources used by the State to obtain control over certain groups in that region.

In this case, we speculate that the proposals of intervening in the space, regarding the catechesis and civilization of the natives were the main strategies to tame undesirable groups. In order to discuss that hypothesis, this work was divided into three sections: the first one discusses the challenges of creating a civilization policy in the indigenous backwoods through the analysis of some of the meanings given to the words "backwoods" and "confines," widely spread in the eighteenth and nineteenth centuries. Subsequently, we are going to present the territorial implications of the indigenous land management policy in the borders. We will also analyze how these areas were steadily transformed into "useful territory" after the changes in the landholding structure and in the investments in infrastructure. Throughout the third section, we are going to exemplify how the civilizing policy of the indigenous people contributed, little by little, to the integration of the area between Campos and Muriaé, a border that was unoccupied by the State until the middle.

Finally, it is worth noting that the area object of analysis is circumscribed between the rivers Muriaé and Pomba, covering a broad region that extended all the way to the fluminense campista coast. That area, which was a natural shelter for escaping natives and black people and was composed of bush land and steep terrain. 


\section{THE DISCOURSES ON THE BACKWOODS AND ITS APPROPRIATION IN THE CONTEXT OF REDEFINING THE STATE'S ROLE}

Amongst several of the meanings for backwoods, confines- and even desert - one notion that seems to have been commonplace is the reference to a faraway area, partially or totally unknown and, therefore, on the verge of being dominated. The idea of distance and isolation is present on Rafael Bluteau's dictionary, edited in 1712, where the word backwoods is defined: "a territory, separated from the sea, and surrounded by land”. One century later, on Antônio de Moraes Silva's dictionary, edited in 1813, the word backwoods é associated with an area/region outside of the cost and on the "countryside". It is, then, the "heart of the land" and, therefore, "opposite to the seaside, and the coast. The backwoods are taken for a forest outside of the coast" . In other words, in this edition, the geographic opposition between coast and countryside seems to be clearer. Such opposition would suggest the paths traveled to reach the "heart", the vital organ that would assure control over the other parts of the "body/space".

Regarding confines, dictionaries indicate that these could be understood as a space that separated the "civilized" area from the others, and which was guarded by a State agent-the "fronteiro". No wonder this person was a reference to the "captain of the border," individual responsible for ensuring the security and extend/expand the boundaries of a given area. This idea is noticeable in both meanings assumed for the term confines: i. "areas located within the limits(extremes) of a Kingdom" occupied by enemies ; ii. "rayas, the extremes and the foreign land border"(Silva, 1813). Thus, the meaning of the words suggested in dictionaries point to some of the State's intentions in this regard: to protect its borders due to the existence of an alleged enemy and at the same time extend the boundaries occupied by "civilized" entities.

The backwoods area already existed, nevertheless, since the moment a meaning was assigned and assumed, and the occupation projects became a reality. In other words, a number of State and privates demands became representative through the discourses about the backwoods and confines, amongst some of them, the conquering and domination over the "land used" by the natives. This territory, symbolically represented, had been tangibly appropriated since the colonial period, when the borders of both the "civilized" and "savage" world began to expand. Without a doubt, that which became known as the "indigenist" policy - a diffuse set of legislation and administrative apparatuses- was outlined to control the bodies of the indigenous peoples as well as their homelands. Furthermore, this policy promoted the dissemination of the "fronteiro" figure, transfigured in the actions of several social actors (missionaries, overseers, farmers, etc) with the intent of conquering the "heart of the land".

From the colonizer's standpoint, "the native was the inhabitant of an indefinable space, incomprehensible, floating, and, above all, nebulous", and, for that reason, "the colonizing project was, first and foremost, transforming the unknown space in a reasonable territory from the perspective of European cultural codes"(MALDI, 1997, p. 189). After the Independence, the newly born nation sets out, as one of its demands, the reconfiguration of its internal frontiers. At that moment, the main concern of the indigenist policy is not just the usage of indigenous labor, but specially the occupation of the "backwoods" and "borders", i.e., the control of places where groups considered "uncivilized" were erratically living. (CUNHA, 2012).

It's no coincidence that the narration of the imperial authorities insisted in highlighting the way of life of the "savages", seen as an impediment to the civilizing projects of the emerging Nation. For that reason, one of the premises of the policy was exactly the sedentarization of the natives, that is, through the redefinition of the idea of indigenous territoriality, process which resulted in the establishment of a new and modern indigenist legislation. As written by Maldi (op. cit, p. 211), such policy had the objective of transforming the "[...] indians in farmers, not necessarily communities, but families, that should receive small portions of land. The Civilizing process means necessarily reducing spaces and involved the dissolution of the "collectivities". 
However, although the territorial demands of the State led to the redefinition of the indigenist legislation through the XIX century, its strategies varied during the course of time, becoming specific for each space where they were applied. Thus, if the indigenist policy had as one of its main goals, during the first twenty years of the XIX century, eliminating the supposed enemies of civilization, later on, in the same century, the views and practices related to the autochthonous nations were redefined. During the $1820 \mathrm{~s}-1840$ s, for instance, several measures were created on the attempt to incorporate the natives to the Empire Nation project. Yet, it was only with the creation of the administrative organs on the backwoods that the methods of control of the gentile were perfected, and manners of punishing the invaders of their lands when conceived. This civilizing advance was connected to the gradual assimilation of the "values of nationality" by the natives, as they started to be seen as an authentic repository of the nation (RIBEIRO, 2009). However, as Cunha (1992) points out, this change only happened in the groups that were well looked after, as were the Tupis-Guaranis .

In addition to these matters, one should note that the debates about the spaces occupied by the natives were being confronted with the thesis about the power of the State, that is, with the notion of public and private rights. On that matter, Maldi (1997) affirms that based on legal aspects, new definitions of territory and territoriality were built at the same time that an idea of Brazilian identity was being forged. In other words, the new indigenist administration policy started to be directed by the right of property and possession, by the right of usage, and also by the idea of belonging to the Brazilian nation.

Based on the diagnosis done by the intellectuals and politicians of the Empire, the main objective of this discipline program for the natives and their homeland was unifying the Nation, which was considered physically an socially heterogeneous. In this respect, José Bonifácio, one of the most important figures of the generation of 1820 and 1830, addressed that, in order to make Brazil more integrated and civilized, it was necessary to raise the productivity on indigenous lands. Amongst several ideas, he would demonstrate how important would be to start colonization centers next to the villages, contemplating the small property. The intention was to fuel the market and to create fairs in strategic places. Thus, from a diagnosis in which the indians were considered idle, lazy and with a lot of vices, José Bonifácio provided the possibility to save them from this stage of savagery.

In this way, amongst the 44 proposals elaborated by him in the year of 1823 and present at the "Apontamentos para a civilização dos índios bravos do Brasil" ("Notes for the civilization of the wild indians of Brazil)", the path that civilized man should follow to promote the integration of domesticated and savage natives to the Nation. Amongst some of their plans, the following stand out: use of the white people justice to mediate land, moral, and religious conflicts; employment of missionaries for the Christening of the natives; placement of indigenous work labor in agriculture and other services; opening to commerce with the indigenous people and control of their production; education of the children; assimilation, via matrimony between natives and Europeans; creation of villages formed by the natives spread through the backwoods and, finally, the gradual conversion of communities into villages.

Inspired on the ideas discussed on the earlier decade, during the 1830 decade several other proposals were put together with the intent of creating a regulation for the indigenous lands. We can mention the Criminal Process Code from 1832, which extinguished the position of "ouvidor da comarca", a "district ombudsman"- a professional previously responsible for the managing of the indigenous fields. Furthermore, there is also the Decree of 1833, putting the cities' Judges of municipal bureaus in charge of the patrimony of the natives.

The indeterminations about whom and through which manner the terrains and the work force of the indians would be managed reflected some of the several problems related to the division of powers -in other words: the dispute between municipalities and the Central Government. Such aspects were manifested mostly with the proclamation of the "Código de Processo Criminal" (Criminal 
Process Code) in 1832 and, years later, with its reform in 1842 . In this context, the administrative incompatibility, the overlaying of powers and the systematic invasion of the indigenous land were the main difficulties encountered by the authorities while managing the homeland of the natives.

Therefore, it is under these redefinitions around the destiny of indigenous lands that the "Regulamento acerca das Missões de Catechese e Civilização" (Regulation on Catechesis and Civilization Missions) was promulgated in 1845 . This Regulation was about the administration of the patrimony of the natives, indicating the responsibility of managing the lands for the State and the "Ordem Menor dos Frades Capuchinhos Italianos" (Minor Order of the Italian Capuchinho Friars). However, it was only a few years later, with the promulgation of the Land Law in 1850, that the politics for the managing of the indigenous land went through a meaningful administrative change. Even though it preserved the idea of Catechesis and civilization, this Law, amongst other aspects, proposed new measures for the regularization of the patrimony of the natives. In this manner the functions of an important branch of the administration of the old Empire is reconfigured: the Catechesis and Civilization of the natives. This branch, in charge of managing the unclaimed land and organizing the indigenous patrimony, legitimized even more the power of the State over the backwoods.

Articulated with the sectors of property, circulation, and colonization security, the indigenous villages and civilization organization policy had the objective of controlling the labor power of the natives through the discrimination of the land that would be considered unclaimed. This movement promoted the expansion of the State institutions and the gradual transformation of the small urban centers within the area where the terrains of the natives were located. We could argue that the bureaucratic organization of this sector enabled the proposal of territory integration as it disseminated values and practices related to the elected nationality model. That is why the imposing of power objects and symbols like chapels, parishes, villages and towns - process that promoted the dilapidation of the indigenous lands - became one of the most effective operations for the dissemination of the model of excluding sovereignty.

\section{A NEW TERRITORIAL ORDER ON THE INDIGENOUS BACKWOODS IN THE BORDER BETWEEN MINAS GERAIS, RIO DE JANEIRO, AND ESPÍRITO SANTO}

The knowledge of the regions and people that inhabit these backwoods, identifying mineral and vegetable potentialities, precedes and accompanies the process of appropriation of indigenous lands, becoming one of the first steps of the occupation program implemented by the Portuguese Crown. Mainly on the XIX century, the potential wealth found in each area and their limits of exploitation started to be more highlighted when travelers, missionaries, and servants of the Crown moved forward into the backwoods. On the reports presented by these actors, the existence of natives and black men, as well as the overdue mentality of the people (including farmers), were considered obstacles to civilization. After all, such elements made it more difficult to exploit the wealth and to populate the new lands.

The preoccupation in "taming the wild" was resumed right after the coming of D. João VI, mainly because of the urgent necessity for supplying the Court, due to the raise in population . This demand intensified the occupation of the surrounding areas in the "backwoods of the east", as named by the civil and military authorities, an important frontier of the Mineiro territory. It was a strategic area inasmuch as it was interesting for the politicians of the old "captaincy of Minas Gerais" , as for the leaderships situated on the north and northeast portion of Rio de Janeiro. Furthermore, it was the target of everlasting conflicts due to its wideness and the unclear territorial limits of the cited "captaincy". After the opening of the "Caminho Novo" (New Path), this area suffered great modifications, mainly due to the demand from the Campos authorities in integrating the Campos village to the region of Muriaé, Pomba, and Espírito Santo. This demand can be observed through the investments done for the opening of roads since the end of the XVIII century, amongst which 
we point out: Caminho do Paraíba (end of XVIII), Caminho Campista do Muriaé (XVIII), Caminho Campista do Espírito Santo (beginning of XIX), Caminho do Pomba (beginning of XIX) and Caminho do Muriaé (close to 1830) .

Thus, with the advance of Portuguese traders into the old captaincy of Rio de Janeiro, south and northwest of Zona da Mata Mineira, helped by the opening of several paths, the disputes between the squatters, farmers, and natives were even harder, especially in the spots marked by the cartography as populated by the "wild indigenous nations".

This process extended during D. João VI's period because, as aforementioned, the Crown encouraged the occupation of the areas under the domination of the natives, granting lands, opening roads, and distributing honorary titles . As marked by Lenharo (1993), such measures were associated with the strengthening of the "mercantile subsistence economy", composing the "modernizing turn" of D. João VI's politics. What explains the creation of the roads and paths in that area is that this spatial practice became one of the main cornerstones of the transport infrastructure plan to integrate the region. This plan, executed by public and private agents (family groups associated to the Crown), had the intention to explore and expand the mercantile economy.

If the concentration of land during D. João VI's period was the central condition for what later would become the coffee sector, as argued by Lenharo (op cit), the change of statute over the indigenous territory (a true novelty in juridical terms) in the next period was one of the main paths to enable such process. In this regard, Cunha (1992) notes that, by the valid legislation, during the colonial period the indians were considered the rightful owners of their lands, and one of the efforts of the political elite on the imperial time was changing that principle. Thus, the new order instituted in the backwoods had the premises of the juridical transformation of the indigenous land and their transference and distribution to the settlers, militiamen, farmers and residents. It was the birth of a new territory, now under the domain of new social agents.

Along these lines, as previously mentioned, the promulgation of the Regulation on the Catechesis and Civilization Missions (1845) operated as one of the main strategies to alter the statute of the land occupied by the natives, process that can be divided in two moments: i.) the first, of a more symbolic order, created the representation of the region as an area of conflict through the narratives that the employees of the Crown, travelers missionaries, etc, would make about the episodes involving conflicts among squatters, representatives of the municipal Chambers, missionaries, farmers, and indigenous peoples; ii.) the second, of a material order, but which also facilitated the dissemination of the values, develop into the installation of infrastructures that aimed at optimizing the navigation on the rivers Doce, Muriaé, and Paraíba and expanding the intra and inter-regional commerce on the provinces, as well as towns, chapels, and settlements.

On the reports and plans elaborated for this region it was clear the intention to modify the usage of the area, integrating it to the economical projects of the Empire. For example, the documental registries highlighted on the Rio de Janeiro and Minas Gerais provinces report a lot of the worries and challenges for the occupation of these region, which became repetitive over several decades: how to better manage the indigenous patrimony, how make these peoples civilized (turn them into catholic and obedient citizens of the laws) and how to expand rural productivity on the areas occupied by the natives. These matters gained more highlight after the expansion of coffee in these border areas, and that reverberated on the civilization and organization theme of the indigenous patrimony on these documents.

Taken as an administrative issue, for the presidents of the provinces it was fundamental to recognize the patrimony of the silvícolas and identify who was truly responsible for their management: de Orphan Judges or the directors of the conservatory. They also affirmed that many Warnings had been created with the intent of regulating the situation of the natives and their villages. Nevertheless, several matters of administrative character are still undefined, like the attribution of the responsible for the villages and the occupation of indigenous lands. 
The concern with this matter was first brought up by the first president of Rio de Janeiro when, in a 1835 report, he talked about the need of better territorial management of the indigenous patrimony. Mourning the problems derived from the extinction of some titles, he proposed the transference to the Chambers of administration and revenue of the natives' goods. So, they would be "subject to the taxes that were managed by the conservatory" (p.9). Embedded with the liberal spirit, the president suggested the alienation of the indigenous lands to the Municipal Chambers with the intention to raise the income of these managerial entities. In his discourse, the preoccupation to reduce the invasions that were happening in some towns where a lot of "intruders" did not pay forum to the Conservatory of the Indians was also highlighted.

Because of the spread out issues of invasion and conflicts, the provincial authorities of Rio de Janeiro required more detailed information about the situation of the natives and their lands. An associate of the IHGB - Joaquim Norberto Silva - was convened to put together the history of the situation of the old and new existent villages in the province. In his awarded work "Historic and documented memory of the indigenous villages of the province of Rio de Janeiro in 1854", Norberto Silva marked that, from the fifteen existent villages, all of them presented problems, such as: invasion of indigenous lands, lack of administrative organization from the government (greatly due to the managing incapability of the judges) and conflicts between natives and squatters. These political and managerial entanglements were also present in other documents, as marked in the provincial president reports.

The idea reminiscent of the Memory and other diagnosis is that during decades the civilization of the natives had no immediate solution. Because of that, in almost all reports the presidents pointed out the general misery of the natives and the complete lack of organization of their patrimony. Even after the Land Law, what remains marked in the provincial president speech in 1863 is the precarious situation of the indigenous land administration, even after a number of managerial measures had been taken:

Not for dereliction nor negligence from the provincial government, but because there are no more savages on the territory of this tribe with contrary habits and hostile dispositions against the civilized population, the service of evangelization is completely abandoned.

Except for the hinterlands of Itabapuanna, Maribeca, and Carangola, where there are still some families of the docile tribes of the Pury race, coming from the backwoods of the neighbor provinces of MinasGeraes and Espirito-Santo, in no other known area are found traces of natives that need to be Christened (RIO DE JANEIRO, 1862, p.35).

Bearing in mind these and other bureaucratic and managerial problems, provincial authorities were worried about the destiny of the indigenous lands and several proposals to promote the civilization and control the work force of the natives. Amongst some of them, the one that envisioned convoking natives for the Navy Arsenal work stood out, as well as the more common ones related to agrarian work on villages and farms. Furthermore, the diffusion of schools was proposed with the intention to "call them to the guild of civilization".

The interest of the local leaderships in not sparing precise information about the patrimony of the natives and the areas considered as unclaimed (partly occupied by them) was also a problem recurrently pointed out by the local leaderships, generally represented by the big farmers.

Despite the strong resistance of the municipalities and the several political and managerial problems faced by the provincial leaders, it seems that administrative procedures disclosed on the reports and other documents -such as those related to the population data, size of properties, and the condition of the natives in these villages- became an important tool for the provincial and central government project imposition of regulation of these lands. Therefore, if there was not a bigger control over the unclaimed/indigenous lands, the occupation of their domains occurred through 
other ways: i.) transformation of communities into villages, division of their patrimony due to the opening of roads and; ii.) incorporation of their lands via strategies of matrimony among the natives and people from European descent.

We must also point out that, if in practically all areas from the province of Rio de Janeiro that were considered civilized, where there were towns, the disappearing of the natives and the disorder of the services was determinate, this reality is not equivalent in the border areas, where there were several indigenous nations in the backwoods. For such areas, a policy that had the clear objective of ensuring the property of the land occupied by the natives was employed. Beyond the set of measures intended for the regulation of backwoods that were adopted, it is important to notice the road opening, river ductwork, and colonization policies that were discussed and encouraged within this context .

In the case of Minas Gerais, the situation of the indigenous lands was not so different, after all, the report from the presidents and the Natives Directors were frequently the same complaints: abandon and difficulty to manage the indigenous land on part of the judges, invasion of their patrimony and state of savagery on the part of the indians spread through the jungles. The proposals of civilization also did not diverge from the other provinces: control and demarcation of the indigenous lands; harnessing of the work power of the natives for the implementation of agriculture and other activities; creation of villages and foundation of institutions for the instruction of the indians (in some cases, the introduction of the elementary and, especially, practical agrarian teachings). All of these proposals had aimed at integrating the natives to the Nation and particularly to the projects of agrarian colonization.

However, the disordered stage of the administrative policy and the situation of the existing villages in this province in the XIX century confronted these ideas. The number of villages presented on the documents by the directors varied a lot, around 12 or 13 - thus, less than the Fluminense province where there were 15 on the mid XIX century. The Natives General Board disorganization was, as was also the case of Rio de Janeiro, one of the main topics addressed by the presidents of the province. The main authorities' complaints did not go through many changes since the beginning of the installation of the Assembly, because the presidents repeatedly mentioned the necessity for more satisfactory information in relation to the native lands. An example of that is the report from 1855 in which the provincial authority observed the lack of accurate information and the existence of illicit profit from many individuals that used the work from the autochthonous.

On the other hand, like the previous example, there was the interest in using indigenous lands in order to continue the modernization projects of the mineiro territory. That can be observed in 1865 , when the provincial authority pointed out that one of the main obstacles, when referring to the project of fluvial navigation on the valley of Rio Doce, was associated to the difficulty to manage the native lands. That aspect was outlined on the report by the responsible for the towns of Minas Gerais in 1869. According to him, the plantation expansion projects bumped into the difficulty to manage the towns that were in a very critical situation:

Since a long time ago, the evangelization in this province can be considered as a branch of service from the public managing. It is only one word or another that can be found here and there, written in some papers, with no importance at all, that exist in the government's chamber. No step has been given in benefit of so many unhappy people that wander through our jungles. To call them to society's fraternity, for the country's own good, would be a great service to humanity and a backing for the plantation that is languishing. (REPORT PRESENTED TO THE PROVINCIAL LEGAL ASSEMBLY OF MINAS-GERAES, 1869, p.24).

The complaints related to the precariousness of the administration of the indigenous patrimony and the conflicts with them remain the same along the next two decades. The discourses of the Natives General Director in 1875 and the president of the Province in 1882 exhibited concerns 
with the endless disputes between the "savages and civilized" for the possession of the land and to implement projects of infrastructure on the conflict areas.

Despite these problems, what can be observed as a development of the managing of the native territories was the expanding of the control methods over that territory, mainly after the second half of the XIX century. Therefore, it is worth noticing that in the Rio de Janeiro province, as much as in Minas Gerais, there was a raise in the number of Native Boards and in the quantity of natives in the villages. For example, at the beginning of the XIX century, there were two native boards in Minas Gerais, while between 1847 and 1858 there were five and, finally, from 1850 to 1855, the records report the existence of six to ten entities with this attribution .

One should note that in certain occasions the government strategically prioritized the installation of towns next to the colonial centers. That was the case of the colony of Mucuri (1852), Dom Pedro II (1856), and Urucu (1854) in Minas Gerais, and the projects of colonization of the Immigration Central Association in Rio de Janeiro. In all of these, the matter of the native land and work force was one of the main concerns of their proposers. The demand from the natives- many times followed by acts of violence - for the non-opening of roads in their lands, was a recurrent request to the authorities. This aspect suggests the dead ends related to the projects aiming at transforming the backwoods of the natives.

Many of the actions directed to these areas were based on the complaints and conflicts involving the natives, revealing that the territorial policy of the Empire featured the appropriation of their lands. This process, from one side, culminated in the alienation of the native patrimony to the Municipal Chambers, originating several towns and villages, and, from another side, in the opening of roads linked to the creation of immigrants' colonies. Bearing this in mind, the development of the administrative apparatus directed to controlling these native's lands is very important, showing the existence of an administrative policy that had the intention to be more systematic. Nevertheless, if, in theoretical terms, the set of Laws and normative instruments were presented in a uniform way, on the practical side, the solutions found by politicians and local leaders were diffuse due to a number of problems, such as lack of resources and a lack of interest (many times veiled) from the government in confronting the power of the local elites.

It appears that the indigenous policy of the XIX century intended to establish a new order for the backwoods. This process was executed through the means of political and administrative apparatus created by the State in order to regulate this territory. The new imagined "order" for the backwoods was structured, as a general rule, through the adoption of the following spatial practices: the creation of villages and military deployments distributed in points that were considered strategic (generally following the rivers' courses); the granting of lands and honorary titles; creation of hermitages (later transformed in parishes and villages); installation of roads; definition and distribution of managing organs directed to the control of the native patrimony; and, finally, the change in the land regime. Amongst these practices, the transformation of the native patrimony in unclaimed lands is a very important one. Considered as one of the main State reforms, it defined a territorial strategy of important meaning: the material and symbolic appropriation of the lands, legitimizing the figure of the territorial State.

Nevertheless, the policy thought out in the XIX century for the occupation of the border areas between the provinces of Rio de Janeiro, Minas Gerais, and Espírito Santo emphasizes that the control of the indigenous lands was one of the main strategies for the State to envision the savagery diagnosed by the political and economical leaderships. Thus, due to the economical advance of sugar during the XVIII century, the great farmers of the old village of Campos had an important role through the land clearing and populating of this region. 


\section{THE EXPELLING OF THE NATIVES AND THE IDEOLOGICAL CONSTRUCTION OF THE INFLUENCE AREA OF THE PAYS OF CAMPOS IN THE END OF THE XVIII AND BEGINNING OF THE XIX CENTURY}

In order to understand the process of indigenous land appropriation it becomes important to analyze the several accounts about the region of Campos and Muriaé. Amongst these accounts, Couto Reys' distinguished itself by its details and employment of a scientific based narrative. Due to the importance and pioneering, the analysis about the occupation of the region will be based on the description and map elaborated in 1875 for the area located between Campos and Muriaé .

The first aspect to be learnt in his accounts is the detailed enumeration of several elements that composed the view. By the means of his descriptions it's possible to notice the presence of rivers and small open paths in the end of the XVIII century and beginning of XIX. Such elements would indicate an articulation amongst the localities inside the District of Campos and Minas Gerais, what would configure a region that is still growing. On this area the main paths (terrestrial and fluvial) are represented, aside from several mills and machinery situated amongst the main rivers and ponds of Campos. It is still possible to notice the civil and religious presence symbolized through the small villages, hermitages, and towns. These elements point out to the economic importance that the old District of Campos had in this context of interest expansion from the Crown. The existence of some paths, embryonic villages, and hermitages (concentrated mainly in the village of Campos), as well as the presence of mills and machinery, following the course of Muriae also indicate that the Village exerted a centrality with its surroundings (see Figure 1).

Like Couto Reys, some other travelers, local leaderships and employees of the Crown would support this point of view when representing the Pays of Campos as the richest and most important from all region:

The Metropolis from this District, the richest, and most populated from all Rio de Janeiro; sustained and enhanced by a flourishing commerce agitated by the products from all subjacent places. It is located over the plains of the Paraíba Meridional Margin, 6 long leagues distant from the sea." (Manuscripts ... $1785: \mathrm{p} 52$ ).

The words metropolis and pays used by the local authorities referring to Campos are noticeable because they do not only enhance the articulations of the village the surrounding localities, but they also suggest the importance that it exerted in relation to its surroundings. That can be observed in the manner which the great area towards Muriaé was pictured, that is: as an area integrated to the village of Campos, a virtually imagined space for the expansion of this so called "metropolis". This region, precariously cartographed with hardly any ways of entrance and with low or none population density, suggested the idea of total emptiness. It also suggested that, as registered on Couto Reys' report, it was a space to be conquered and civilized, because of the natives' presence, thus, requiring measures to discipline them. The advance of some farms following the course of the river Muriaéthe main path that connected this region with the area that was mostly populated and controlled by the Crown - would make up a sub-region, where corrective measures were recommended in order to clear the problems of the pestilent backwoods, such as: the opening of roads, rivers droughts, and the creation of new settlements.

As a legitimate representative of the Enlightenment thought, his proposal was embedded with the desire to propel the river and canal navigation in order to transform the "state of savagery of the backwoods" and integrate them to order. Therefore, while indicating such need the report of Couto Reys would praise the value of the main "blood vessels": the rivers and lakes of the region. According to him, through the expansion of fluvial navigability it would be possible to articulate the region and better explore its wealth. It is not by chance that, in order to expand towards Muriaé, the economy of this area supposedly belonging to Campos, the fundamental proposals of the 
Captain pursued to make the rivers and lakes navigable, increasing the commerce of products that were locally produced and promoting the civilization of the people that inhabited these backwoods.

The depiction of Campos as a "metropolis" on the writings of Couto Reys was totally, or partially, reproduced on the future reports and projects that proposed the alteration of this wide region led by Campos. According to the Captains' perspective, due to the wealth and "energy" of its men, Campos would be suited to lead the land clearing of this virtual space that was found on the surroundings. Moreover, this destination would still be reinforced by the following aspects: location and commerce on the village; its integration to the João da Barra harbor (main harbor for the outflow of food products); and the existence of a wide hydrographic network and the presence of very fertile soil. It was certainly the most populated village from the region and the one that had the most number of churches, houses, villages, and unpaved roads. It was the center of the Campos District and the head of the County.

The memory of Couto Reys operated as one of the main starting points for the creation and recreation of an image that associated wealth and richness of a whole region to the natural features of the campista landscape. Therefore, it reinforced an idea that was followed by the political leaders of the XIX century to occupy the village and the area through bigger investments on the transport network, mainly the rivers and roads.

So then, with the crossing of different social practices established by the Crown, local authorities, missionaries, amongst others, the vast domains once occupied by the natives started to be conquered since the end of the XVII century, intensifying the conflicts on the area through the following century. That way, the future population of the backwoods between Campos and Muriaé and its transformation, during the XIX century, in a productive and integrated area to the coffee and sugar markets is a result of this symbolic appropriation.

In the XIX century, almost all areas demarcated and represented as backwoods served as shelter for the natives and, consequently, were considered an expanded region from the "Metropolis" of Campos. They were located on the north, northwest, and south borders of Rio de Janeiro, on the so called "backwoods of the wild natives", where the Coroados and Puris lived - nations which were considered enemies. At this moment, due to the barriers imposed by the autochthonous to the occupation of these areas, the authorities' objective was to reduce them and establish villages that aimed at guaranteeing the sovereignty of the Crown and assuring work labor for the residents. In the case of older towns, many of which were located next to the villages and whose contact and assimilation with the colonial society was previous, the indigenist policy proposed their extinction or dislocation to other areas, as it was already happening.

The more systematic proposals of occupation of this vast area, encompassing Campos and Muriaé, had begun in this context. They involved the breakthrough and the conquering of a wide territory, in a manner that the profits of the sugar-cane-based economy were increased and the necessity of supplying the Court became urgent. Integrated in a program of occupation from the Marquis de Lavradio and in the middle of confrontations with the natives in their lands, the area started to be the target of permanent visits in the XIX century. Amongst the "visitors" there were missionaries, militaries, travelers, and also several Crown officials, as was the case of the field masters. Later on, these men, composed partly by the local elites interested in the conquering of new areas, contributed by feeding information about the backwoods and unraveling measures that aimed at promoting the order of the areas of conflict. 


\section{OCCUPATION OF THE NATIVES' BACKWOODS IN CAMPOS AND MURIAÉ ON THE VERGE OF THE XIX CENTURY}

With the crisis installed after the Independency and during the regency period, the so called "sugar civilization" - as mentioned by Lamego (1996) - reinforces the interest of more visibility to the region of Campos-Muriaé employing all the resources to transform Vila de Campos in a regional center on the north of the province.

Thus, the discourse of the local leaderships that highlighted the wealth of the area was increasingly managed to justify the projects of integration of the new spaces, up until they were considered empty or improperly occupied. Therefore, the project of almost all of the XIX century was to expand the usage of the natural paths in order to articulate the local commercial centers to the different productive areas. It is worth noting that most of the area proposed for the implementation of this program was occupied by squatters and natives.

The propaganda around the potentiality and occupation of the new areas was put forth by a number of local leaders, but there is no doubt that, after the Memoir written in 1819 by José Carneiro Silva, those and other ideas gained more visibility among central authorities. In a way, to repeat some points stated by Couto Reys, the opulence of Vila de Campos in the period was a result of the soil's potentiality, the wide hydrographic network, and the courage of their men. So, he insisted on the need of a bigger investment in the area aiming at amplifying this almost natural "gift".

In parallel fashion, when relating the wealth of the place to the lovability of its people, Muniz de Sousa, a traveler who visited Campos and its surroundings between 1827 and 1828, registered and referenced the same perspective over the environmental features of the village and the area:

The terrains of Campos are the most productive and fertile that can be for manioc, corn, beans, rice, coffee, and any other plantation [...]. The agriculture of Villa de S. Salvador dos Campos dos Goytacazes has a considerable advantage due to the free fruitfulness of the lands, that, as if committed to facilitate the work of the farmer that cultivate them, produce the vegetable germs that diffuse over them (SOUZA, 1834, p.. 117).

These and other descriptions of the land, reproduced and advertised by local groups, as much as by travelers and missionaries from the XIX century, reinforced, to an extent, what was proposed in the Manuscript of Couto Reys: they wanted to spread the idea of a supposed "regional vocation" of Vila de Campos. The discourse advertised by the local leaders launched an argumentative matrix that was employed in almost every moment to justify the several territorial projects in Campos, amongst which stands out the project of turning it into the new capital of the Empire, transforming the capital into a new province - the Province of Goitacazes (CHRUSOSTOMO, 2009b).

One of the occupation plans reinforced the idea over the need of occupying the land situated on the valleys of Muriaé and its affluents, where there was practically no economical activity during several centuries. For clearly being a reserve space - whose occupation was prohibited by the Crown in the XVIII century due to the danger of gold miscarriage - such area only became part of a more intensified policy of intervention mainly since the second decade of the XIX century. Its exploration was a consequence of the conjunction of several territorial expansion projects and the occupation of the borders in these vast backwoods. Amongst some of the matters that were present in these proposals, we should notice: the expansionist interests of the provinces of Minas Gerais, Rio de Janeiro, and Espírito Santo; the integration of new spaces through the construction of roads or the potentiating of the use of rivers; disciplining or eliminating the natives through towns and, finally, the eradication and control of undesirable peoples: savage natives and black men from the quilombos. Nevertheless, it still is target of controversies the manner through which this enterprising was performed. 
One of the points of view that have been used to explain the growth and integration of the region of Muriaé, since the XIX century, to the Fluminense economy highlights a clear relation, from the end of the XVIII century onwards, with the north and northwest of the province of Rio de Janeiro. This point of view signals the existence of sugar cane mills on the lower part of Muriaé, as confirmed by the maps and reports of Couto Reys, from W.L. Von Eschwege and Prince Maximiliano . It also indicates the existence of an alimentary items commerce that would have expanded with the opening of some. In that respect, several cartographic representations elaborated on XVIII and XIX centuries indicate, although with inaccurate limits, a region composed of several localities mineiras (including Muriaé) and connected to the Vila de Campos. The last is noticeable, as observed on Figure 1, for presenting the largest volume of civil and religious devices, like hermitages, villages, paths, mills, etc.

These reports noticed the importance of a economical and political relation with the old Capitancy of Rio de Janeiro, grounded on the exchange of food products, such as "cattle, beasts, cheese, bacon, pork" (SILVA, 1891). This relation states an articulation, even if subtle, of the areas registered as backwoods on the Vila de Campos . Bearing in mind the expansion of this commerce on the beginning of the XIX century, these areas, before being occupied by the mineiras troops, received frequent incursions of herbalists, dealers and squatters, originating from Vila de São Vicente, from Campos and the Empire's capita. In front of this frail, yet important articulation that occurred through the navigation of the Muriaé river and its affluents, new routes were sketched, exchanges were established, and borders were expanded. Gradually, followed by the success of the poaia and first need products, small harbors appeared on its brinks and margins.

Therefore, it was through a fluvial and also terrestrial based economy that this village population grew, maintaining its close connection to Vila de Campos. Lamego (1992) had already observed this relation between the river Muriaé and Campos by affirming that at the end of the XVIII century there were about twenty mills on the region of the lower Muriaé. Nevertheless, during the Imperial era, due to the installation of the farms, attribution of titles, and constitution of estates, he pointed out a significant change on the landscape surrounding this rivers' valley, since the "muriaeense bay had been definitely occupied". According to the author, one of the greatest figures was José de Lannes Dantas Brandão (a mineiro police volunteer) who had been a refugee in Campos during the Revolution of 1831 . He would have been one of the responsible people for the opening of the border of the higher Muriaé. But the medium course of this river, named by Lamego as the "Bandeira do Jacarandá", was pioneered by João Lopes da Silva, who died after installing a little dwelling on the Santo Antonio de Carangola camp.

If the investments of privates and the Crown towards Campos-Muriaé were aiming at expanding the barriers from this considered "wild" region, afterwards, with the development of the coffee plantations, the landscape of this wide region would present very symbolic changes, especially after the middle of the XIX century. That aspect can be observed on the Parochial Registries of the Land of Muriaé, which reveal the intense transformation of the usage of the lands due to the elevated land-holding concentration on the locality (ANDRADE, 2007). However, even though the coffee economy would start to dominate the landscape after the middle of the XIX century, the plantation of food items was still practiced by most part of the small and medium owners. The most important products were the cultivation of corn, sugar, bean, as well as animal breeding. Even if such agrarian genres indicated the influence of indigenous habits, for example, with the growth of corn, the presence of these owners was nearly unperceived on the Property Registries .

The new geographical and political outlines assumed by the region of Muriaé are related to the paths covered in order to enable the production, commerce, and distribution of agrarian genres, especially coffee. (MERCADANTE, 1973). The march of the Rubiaceae, thus, reflected the different paths taken by the farmers when breaking through the borders of the backwoods located 
between Muriaé and Campos and the regulation strategies from these lands previously occupied by the natives.

However, if coffee marked its presence in the landscape of the XIX century, other social processes preceded it, so that the occupation and integration proposal related to this territory, by the end of the XVIII century, were essential to define the contours of the region. Accordingly, the transformation of the natives' land into unclaimed territory, the occupation of the highlands by squatters, the opening of roads in the north and northwest of Rio de Janeiro (linking the area to the southern portion, and to the East Zona da Mata Mineira) as well as the installation of a network of hermitages and villages played a central role in the process of clearing that territory.

In a way, linked to the first interpretation about the process of occupation in Muriaé, another point of view highlights the development of the region in the XIX century as a result of the endeavors of Luiz Cunha Meneses, then governor of Minas Gerais Captaincy. Among other aspects, this authority saw the region as a strategic point for the defense of the province against internal enemies -ie the natives and the campistas leaderships who settled mills and machinery in the Muriaé river. Thus, their occupation was linked to two clearly articulated movements: the valorization of this area due to the expansion of agrarian economy and the guarantee of the areas located on the southern and eastern outskirts of Minas Gerais.

Because this region was occupied by the natives, Guido Thomaz Marlière, hired by the Minas Gerais Captaincy governor to investigate the limits and the possibility of occupation of the area, had an important role in its exploration. At the end of 1813, he arrives at São João Baptista do Presídio, sent by Count de Palma, governor of the Captaincy, with the task of pacifying the conflicts involving the area's Portuguese squatters and natives. Due to the success of this mission he was named "General Director of the Natives on the Parish of São Manoel do Rio Pomba (currently Rio Pomba), São João Baptista do Presídio and surrounding Villages" . Due to his abilities with the Puris natives, several settlements, amongst which Muriaé, received their first inflow of population from European origin that came from the center of Minas (FURTADO, 2009).

Thus, arising from the endeavors in the backwoods, the birth of the Village of São Paulo Manoel Burgo - current Muriaé - pioneered the work of Constantino José Pinto, who, to fulfill orders of Guido Marlière, came to the location around 1819 after going through the margins of the São João do Monte and Robinson Crusoé banks -affluents of the Muriaé river. In a real military operation, Constantino reached the region escorted by about forty soldiers with the intention to pacify, catechize, and consolidate the village of the Puris natives, later being appointed as director of the natives' village. The bases for the occupation of the incipient settlement in the Muriaé river were raised through the village of these natives and the respective demarcation of land for the plantations and the support of the natives.

The Deputy Director of the natives, who had been responsible for the management of their land for thirty years, promoted the growth of the then village of São Paulo do Manoel Burgo, expanding the trade of poaia, a medicinal plant of great value at the time. Apparently his wealth grew substantially while he was deputy director, having assets in land, cattle, objects, money and slaves in the inventory.(MARGE, s/d).

The wealth and interest in occupying this region promoted the visit of several travelers, amongst which the baiano Muniz de Souza, who explored it on the 1820's with the intention to know and indicate its potentialities. At the moment he reported a necessity to give a new destination to the lands of Muriaé, due to its natural riches. According to him, the proximities of the Muriaé river presented several outstanding features: powerful lowlands that were favorable to the plantation of sugar cane; nutritious mimoso grass pastures; forty eight sugar mills available in their margins and some potteries and villas. Amongst other details, the traveler also performed an analysis of the soil and observed the great potential of the massape terrains for the plantation of cane, suggesting the 
development of this activity on the plains, so that the hills could be free for the cattle and other plantations.

Therefore, although sharing common elements, the occupation of this border would have been the result of the occupation policy propagated by the leaderships located in Minas Gerais. Work of conquest from a government that had affirmed the power of its leaderships on these backwoods disputed by farmers and political leaderships from Rio de Janeiro.

It is important, nevertheless, to notice that, following the paths of the rivers, the backwoods were cleared. The backwoods, according to the aforementioned data, did not have a clear outline, once it was an area of permanent conflict. However, on the dispute for these backwoods' representation -involving authorities from Minas and Campos - up until its effective occupation, what was clear was the annihilation of the mamelucos, of the natives, and of the black men in the quilombos. After all, the idea was installing new activities due to the necessity of expanding the agrarian economy. Therefore, it was the power and efficacy of the local and regional forces that defined the limits of the borders of this wide backwoods, guaranteeing the material appropriation of the natives' lands.

\section{FINAL CONSIDERATIONS}

The backwoods of Campos and Muriaé were areas featured by a slow temporality and by "slow men". The shock of temporalities meant, within that context, the confrontation of several projects and uses of the territory, transforming these backwoods into a region of permanent conflicts all the way through the XIX century. The imposition of a new time resulting from the spatial transformations built by the civilizatory project had the purpose of eliminating the natives' backwoods. After all, it was marked by the temporality and spatiality that was opposed to the liberal order.

Therefore, one of the intents of the natives' civilizatory policy was the construction of an image of the backwood as an area where there would happen an unpredictable irruption of the savages. The backwood would disappear, because it was unsafe due to a geographic reality that contained men scattered through great paths covered in virgin forest. The future of the Imperial Nation did not admit the isolation, let alone human groups disengaged from the social order that was considered civilized. From the leaderships' stand point, the ideal geographical order was the fixation on the territory rather than the dispersion, which was common to the natives.

The fixation and dislocation are, within this scenario, the main elements of the modernization project for the backwood areas. Accordingly, the central matter is not just the control over the territory, but also over the very own body of the natives, who were obliged to be sedentary, presenting so called civilized behaviors.

But what was civilization? It was the love of property, the Catholic religion, and morality. These were the paths that would lead to the progress of society. Therefore, a civilized Nation could not admit men who had no love for property and who did not obey the law, that is, that were not tied to territorial limits imposed by the State. So that the country could "go forth", the natives were supposed to remain immobile and learn to live in a reality that was completely alien to them. As it has been demonstrated along these pages, this idea of "going forth" only made sense to a few small groups, like the great farmers. And how about the interests of the natives? Those were left behind.

\section{BIBLIOGRAPHIC REFERENCE}

ALMEIDA, M. R. C. Os Índios no Tempo da Corte: reflexões sobre política indigenista e cultura política indígena no Rio de Janeiro Oitocentista. Revista USP, v. 79, p. 94-105, 2008.

ANDRADE. V.F.S. Ocupação e formação econômica dos sertões do Muriaé. In: Simpósio Nacional de História - História e Multidisciplinaridade: Territórios e Deslocamentos. São Leopoldo: Usinos. Anais...do XXIV Simpósio Nacional de História da Associação Nacional de História - ANPUH, 2007. 
BARROSO, G. A origem da palavra "Sertão". Boletim Geográfico. Rio de Janeiro: IBGE, V(52): 401-403, junho, 1947.

CHRYSOSTOMO, M. I. J. Os colonos franceses da colônia Valão dos Veados - 1845-1854. VIDAL, Laurent e LUCA, Tania (orgs). Franceses no Brasil - séculos XIX e XX. Unesp: São Paulo, 2009a.

CHRYSOSTOMO, M. I. J. Campos: a capital sonhada de uma província desejada (1835-1897). História vol.30 no. 1 Franca Jan./June 2011.

CHRYSOSTOMO, M. I. J. Uma Veneza no sertão fluminense: os rios e os canais em Campos dos Goitacazes.

História Revista (UFG. Impresso), v. 14, p. 1-22, 2009 b.

COUTO REYS, M. M. Descripção geographica, politica e cronographica do districto dos Campos Goiatacaz. Rio de Janeiro: Arquivo Público do Estado do Rio de Janeiro, 1997 [1785].

CUNHA, Manuela Carneiro da. História dos índios no Brasil. São Paulo. Fapesp/SMC/Companhia das Letras, 1992.

CUNHA, M. Carneiro da. Índios no Brasil: história, direitos e cidadania. São Paulo: Claro Enigma, 2012. DIRETORIA GERAL DOS ÍNDIOS DA PROVÍNCIA DE MINAS GERAIS. 1863-1894.

FURTADO, Júnia Ferreira. Trajetórias de franceses em Minas Gerais no século XIX. In: LUCA, Tania Regina de; VIDAL, Laurent. (Org.). Franceses no Brasil: séculos XIX-XX. 1 ed. São Paulo: UNESP, 2009, v. 1, p. 369-386.

LAMEGO, R. A. A Planície do Solar e da Senzala. Rio de Janeiro: Arquivo Público do Estado do Rio de Janeiro (Coleção Fluminense), 2ª edição, 1996.

LENHARO, A. As Tropas da Moderação. Rio de Janeiro: o abastecimento da Corte na formação política do Brasil - 1808-1842. Rio de Janeiro: Prefeitura da cidade do Rio de Janeiro, Biblioteca Carioca, $2^{\mathrm{a}}$ edição, 1993.

MALDI, Denise. De confederados a bárbaros: a representação da territorialidade e da fronteira indígenas nos séculos XVIII e XIX. Revista de Antropologia, São Paulo, USP, vol. 40, n. 2, p. 183-221, 1997.

MARGE, A. et al. Prefeitura Municipal de Muriaé. Muriaé: 150 anos de História. Revista Comemorativa do Seisquicentenário de Muriaé - 1855-2005.

MERCADANTE, Paulo. Os sertões do Leste. Estudo de uma região: Mata Mineira. Rio de Janeiro: Zahar, 1973

MINAS GERAIS (Província). Presidência da...Relatórios da...Minas Gerais, 1850-1880.

MORAES, A. C. R. Capitalismo, geografia e meio ambiente. 2000, 202f. Tese (Livre Docência) Faculdade de Filosofia e Ciências Humanas, Universidade de São Paulo, São Paulo, 2000.

MORAES, A. C. R. O Sertão: Um “Outro" Geográfico. s/p. TERRA BRASILIS - Revista de História de Pensamento Geográfico no Brasil Anos III - IV, N. 4-5 - Território, 2002-2003 Rio de Janeiro, RJ.

MORAES, A. C. R. Território e História no Brasil. São Paulo: Ed. Hucitec, 1988.

OTONI, Teófilo Benedito. 1859 [2002]. Notícia sobre os selvagens do Mucuri em uma carta dirigida pelo Sr. Teófilo Benedito Otoni ao Sr. Joaquim Manuel de Macedo. In: DUARTE, Regina Horta (org.). Notícia sobre os selvagens do Mucuri. Belo Horizonte: UFMG.

PINTO, L. M. S. Diccionario da Lingua Brasileira por Luiz Maria da Silva Pinto, natural da Provincia de Goyaz. Na Typographia de Silva, 1832.

REGISTROS PAROQUAIS DE TERRAS DE SÃO PAULO DO MURIAHE. 1854-1867.

RIBEIRO, N. B. Catequese e civilização dos índios nos sertões do império português no século XVIII. História (UNESP. Impresso), v. 28, p. 320-345, 2009.

RIO DE JANEIRO (Província). Presidência da...Relatórios da...Rio de Janeiro, 1835-1870.

SENA, C. S. A categoria sertão: um exercício de imaginação antropológica. Sociedade e Cultura, Editora da UFG, v.1, n.1, p.19-28,1998.

SILVA, A M. Diccionario da lingua portugueza - recompilado dos vocabularios impressos ate agora, e nesta segunda edição novamente emendado e muito acrescentado, por ANTONIO DE MORAES SILVA. Lisboa: Typographia Lacerdina, 1813. 
SILVA, J. C. Memoria Topografica e Histórica sobre Campos dos Goitacezes com uma noticia breve de suas produç̧ões e commercio offerecida ao mui poderoso Rei e Senhor Nosso D. João $6^{0}$. Por Natural do Mesmo Paiz. Rio de Janeiro. Impressão Regia, 1819.

SOUSA, A. M. Viagens e Observações de hum brasileiro que desejando ser útil á sua Patria, e os três reinos da Natureza, em varias lugares e sertões do Brasil, offerecidas á Nação brasileira. Rio de Janeiro: Impresso na Typ. Americana de I. P. da Costa. Tomo Primeiro, 1834.

Submitted october 2015 Accepted december 2015 